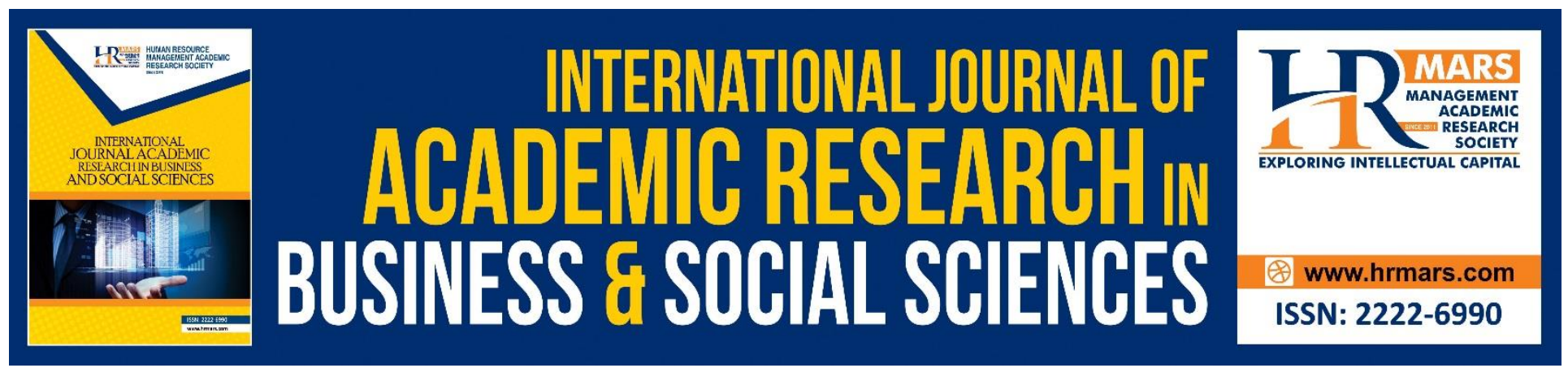

\title{
The Relationship between Ethical Leadership and Work Engagement: Moderation of Machiavellianism
}

\author{
Ume Habiba, Syeda Sidra Tasneem Kausar, Ali Waqas, Kalim Ullah
}

To Link this Article: http://dx.doi.org/10.6007/IJARBSS/v9-i3/5808

DOI: $10.6007 /$ IJARBSS/v9-i3/5808

Received: 01 Feb 2019, Revised: 12 Feb 2019, Accepted: 23 Feb 2019

Published Online: 24 March 2019

In-Text Citation: (Habiba, Kausar, Waqas, \& Ullah, 2019)

To Cite this Article: Habiba, U., Kausar, S. S. T., Waqas, A., \& Ullah, K. (2019). The Relationship between Ethical Leadership and Work Engagement: Moderation of Machiavellianism. International Journal of Academic Research Business and Social Sciences, 9(3), 1447-1459.

Copyright: (C) 2019 The Author(s)

Published by Human Resource Management Academic Research Society (www.hrmars.com)

This article is published under the Creative Commons Attribution (CC BY 4.0) license. Anyone may reproduce, distribute, translate and create derivative works of this article (for both commercial and non-commercial purposes), subject to full attribution to the original publication and authors. The full terms of this license may be seen at: $\underline{\text { http://creativecommons.org/licences/by/4.0/legalcode }}$

Vol. 9, No. 3, 2019, Pg. 1447 - 1459

http://hrmars.com/index.php/pages/detail/IJARBSS

JOURNAL HOMEPAGE

Full Terms \& Conditions of access and use can be found at http://hrmars.com/index.php/pages/detail/publication-ethics 


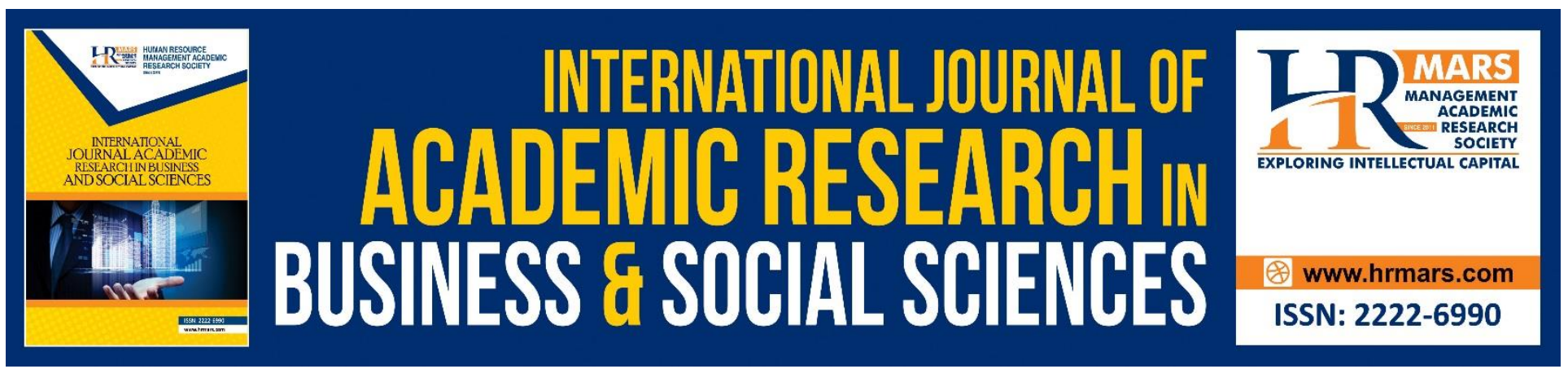

\title{
The Relationship between Ethical Leadership and Work Engagement: Moderation of Machiavellianism
}

\author{
"Ume Habiba', Syeda Sidra Tasneem Kausar², *Ali Waqas³, \\ Dr. Kalim Ullah ${ }^{4}$ \\ ${ }^{1}$ Post RN, Nursing College, The Superior College Lahore \\ ${ }^{2}$ Director, Nursing College, The Superior College Lahore \\ ${ }^{3,4}$ Lecturer, Nursing College, The Superior College Lahore \\ *Email: ali.90waqas@gmail.com
}

\begin{abstract}
Leaders those having a motivational behavior impose a great impact on follower's behaviors. These leaders create their own values, believes. Ethical leadership create a great effect on self-concept and beliefs of followers. The effect of ethical pioneers' behavior on work engagement is decreased for leader who have not kept their original and public character in the same line. The connection among the ethical management and followers work engagement is moderated by means of pioneers ranking on Machiavellianism. The leader Machiavellianism act as a moderator in the relationship between ethical pioneers and employee work engagement. The purpose of this study was to find out the influence of ethical leadership on work engagement and to test the role of leader Machiavellianism in the relationship between ethical guidance and work engagement. Correlational study was conducted to measure the work engagement and Machiavellian in the ethical leadership process. A Self- administered questionnaire was floated to collect data from charge nurses. The results of the study showed the positive significant relationship between the ethical leadership and work engagement and insignificant relationship of Machiavellianism in the relationship between ethical leadership and work engagement. This study argues that when leader is highly Machiavellian then the positive effects of leaders are repressed. The study also shows that effect of ethical pioneer conduct on work engagement are poor when moral leaders are highly Machiavellianism.
\end{abstract}

Keywords: Ethical leadership, Work Engagement, Machiavellianism

\section{Introduction}

The important questions regarding the part of leadership in forming the morally good behavior have raised because of the current ethical misconduct in business. There is unethical leader that have seen in the world, who try to obtain their personal desires at the cost of their organization. For manager 
and educational researcher ethics is partly connected to leadership. Leadership should have an moral structure for achieving the constructive framework over the long time (Demirtas 2015).

"Ethical leadership is defined as the presentation of proper guidance over with distinctive actions, interactive relations and development of such behavior to assistance through two way transmission, strengthening and decision making (Brown, Treviño et al. 2005)".

The research on moral administration demonstrates that ethical leader moves elevated amounts of responsibility, trust and encourage useful practices among supporters. Ethical leadership like charismatic authority involves a type of leadership derives from the charisma of the leader. Those leaders who follow values strictly definitively effect on self-structure and conduct of their companion, they also effects on their inspiration, postures and demeanors.

According to motivational process that stress on ethical assistance and trustworthiness, kind and equitable which modeled by ethical leader encourage the work engagement employees. It also enhances the organization production and worth (Den Hartog \& Belschak, 2012).

People who wrote about work engagement process believes that representatives and followers gives higher output or show more interest when they see that their pioneers are more cooperative gives more dedication to work (Harter, Schmidt et al. 2002). This is just a transformational process work on, if we pay more dedications to work more struggle more work output. This type of positive authority would consequently be relied upon to decidedly identify with levels of workforce engagement.

Leader who follow immoral trait significantly mistreat their institution. While those who follow moral principle, their behavior is more beneficial for their institution. So, it is more demanding to have more research on ethical behavior of leadership, because ethical leadership promote positive interpersonal relationship between leader and their followers because this positive interpersonal relationship between leaders and employees increase trust among them, which also positively effect on organizational work (Walumbwa \& Schaubroeck, 2009).

Machiavellianism is a perspective of the world where person may not on a very basic level be trusted, therefore a Machiavellian, utilizing, closes justifies the methods, convictions, search for control over others and status for themselves (Hunter, 2012). Machiavellianism should be respected as a quantitative trait. Moral pioneer has less effect on work engagement when ethical pioneer is high Machiavellianism.

Leader behavior either they act ethically or not is very important for followers because when leader start to create an extra pressure then a judgmental environment create an extra pressure between leaders and followers that badly effect on their behaviors. Some leader though they are not ethical in behavior but to prove as ethical they create an extra pressure to generate an ethical impact for their followers. This unique problem is devoted to ultimate some of the gaps in our understanding about these bad aspects of individual differences, mainly the position that darkish character plays within the workplace.

The Aim of this study is to inspect the association between moral leadership and its result have on work engagement employees and to test the part of leader Machiavellianism. It is also examined that how supporter react when conflict occur between the leader's show, popular originality and personal originality. In a meta-analytic study observed that public, response, positive organizational climate and self-efficacy are empathetically related to engagement. Actually, despite the fact the association 
between moral guidance and work engagement rests to be examined, these finding assist our theoretical reasoning that a correlation is in likelihood.

The effect of moral pioneer's behavior on work engagement is decreased for leader who have not kept their original and public selfhood in the same line. The connection among the ethical management and followers work engagement is moderated by means of pioneers ranking on Machiavellianism. Particularly, the relationship between ethical behavior and adherent is weak if moral behavior is inauthentic than those who have authentic behavior (Hartog \& Belschak, 2012).

\section{Research Objectives}

- To find out the effect of ethical leadership on work engagement.

- To find out the role of leader Machiavellianism in the relationship between ethical guidance and work engagement

\section{Problem Statement and Significance}

The study shows that for organizational success work engagement is increasingly important outcomes. Employee will be productive and perform well in the organization when they are engaged in the work. Employee are not engaged with his job in the organization causing decreased patient satisfaction, decreased organizational outcomes. This is because of the negative personality of the leader that does not produce the ethical climate within the work environment. The Machiavellian personality of leader have negatively effect on the work engagement. In order to develop and encourage the phenomenon to contribute engagement the importance of work engagement has to stress. Leader and followers should develop trusting and ethical relationship to enhance work engagement.

This research can be helpful for supervisor while dealing with nursing staff, If the level of engagement is studied supervisor can enforce and implement changes that would actually improve engagement. Leader should create working environment that leads to engagement from themselves and from the staff. If the work engagement improves then client satisfaction increase that is beneficial for the staff and organization. Leader who act ethically in institution and recognize their followers need then it is beneficial for the institution that subordinate work intensely.

\section{Literature Review}

Ethical leadership is going on a trend. Leaders those having a motivational behavior impose a great impact on follower's behaviors. These leaders create their own values, believes. A successful or powerful rewarding system and motivational attitude create a strengthen effect on followers. Ethical leadership create a great effect on self-concept and beliefs of followers. This type of behaviors acts as a role model for followers. In addition, the literature on ethical leadership argue that the main component of ethical leadership is the verbal exchange and out word satisfaction of moral importance and behaviors.

Ethical leadership deal with the movements, convince someone and different behaviors that control suitable standards. Ethical pioneers reveal "Normatively appropriate behavior through personal actions and interpersonal relationships (Hartog \& Belschak, 2012)". Some of the personal characteristics which might be associated with moral leadership were found. Ethical leaders behave 
INTERNATIONAL JOURNAL OF ACADEMIC RESEARCH IN BUSINESS AND SOCIAL SCIENCES Vol. 9, No. 3, March, 2019, E-ISSN: 222 2-6990 @ 2019 HRMARS

in a good manner in everyday way of living and observe as truthful, Ethical. The researcher specifies these characteristics as the good view of moral management.

In ethical leadership researcher use social learning theory to elaborate the result of ethical pioneers. According to social learning theory, leader must be seen as gorgeous and reliable model for their followers. There are a number of situations identified in ethics and leadership literature that increase the leader attractiveness and credibility. Individual learn by noticing the attitude and performance of their leader based on social learning theory (Brown \& Treviño, 2006).

In work engagement, Vigor is categorized by way of excessive level of strength and intellectual resilience as the same time as working and the willingness to make investments efforts in one's work and patience in difficult situation. Dedication mean energetically concerned in work, experience of implication, feeling of excitement, thought, satisfaction with achievement, and project. Absorption is characterized by way of being intensely focused and absorbed in a single work, where time pass speedy and requiring great effort when separated oneself from work (Hassan \& Ahmed, 2011).

Research suggest that employees, engagement with their work is an essential predictor of task pride and intentions to remain within the organization. Developing situation that work engagement is an crucial mandate of nurse management and a key element of any recruitment and retention (Laschinger and Finegan, 2005). People who wrote about the work engagement process believes that representatives and followers gives higher output or show more interest when they see that their pioneers are more cooperative gives more dedication to work (Harter, Schmidt et al. 2002).

This study attempts to deal with this problem by way of taking chief Machiavellianism under consideration. They think of themselves as they skillfully control events of others, although their ability to identify and manage emotions is not as strong as their self-identity to seek to influence. When they work without formal organization or structure, less organized setting then they measured his success relatively in their career. Their success tends to reduce as organizational structure get bigger. They are not surely feeling of disapproval by others, but rather they are not outstandingly effective while engaging in political activity.

The leader Machiavellianism act as a moderator in the association of moral pioneers and work engagement. Dahling et al. (2009) depict Machiavellianism, which involve in model as a moderator, which restrain from inner faith, appreciation and encouragement. Machiavellians followers though they do not strictly follow the moral values, But they have adoption abilities inherently.

According to social exchange theory prediction, Machiavellianism are going to be negatively related to job performance. Some work situation need cooperative convention with others. For example, group member support each other's, salesperson develop relationship with customer, subordinate meet their commitment as a result of they are loyal to their manager, team and institute; followers trust with their leader but Machiavellians tendency weak their connection with others when they violate principle of social exchange. As a result, Machiavellians are not successful to fulfill the demand of business career.

Most of the leader have ethical issue in their field with subordinate that's why their result is not good regarding work engagement. They are more likely to cheat, lie, and disloyal others, but they do not regularly involve in outstandingly negative forms of antisocial behavior (Forsyth, Banks et al. 2012). Leader who have not kept their self- identity and outward identity in line than the positive affect of moral leader on work engagement is decreased. The study shows the effect of moral leadership on 
INTERNATIONAL JOURNAL OF ACADEMIC RESEARCH IN BUSINESS AND SOCIAL SCIENCES

Vol. 9, No. 3, March, 2019, E-ISSN: 222 2-6990 ¿ 2019 HRMARS

work engagement are poor when moral leaders are highly Machiavellianism (Hartog \& Belschak 2012).

\section{Methodology}

This heading describes the method and procedure that was applied in this study.

\section{Total Population and Sample Size}

The research design was correlational study. The target population was 150 nurses from College of Nursing Allama Iqbal Medical College Lahore.The total sample size of 110 nurses were randomly selected from the total population. The participant were belong to different socioeconomic level and demographical background; the participant are male and female.

\section{Research Instrument}

This research have three variables, Ethical leadership (Independent variable), work engagement (Dependent variable) and Machiavellianism (Moderator). That is why the questionnaire used in this research was adopted from three articles. The 10-item scale questionnaire "To measure employee's perception of their leader,s ethical leadership behaviour by Brown et al. (2005)". work engagement measured by 9-item scale by Schaufeli and Bakker (2004) and Machiavellianism measured with 8item version of Mach-iv scale of Christie and Geis (1970). The instrument was divided into two section ( $A$ and $B$ ). Section A contains demographic data while Section B comprised of five scale lickert scale that obtained responses from the respondents with response options: 1 ("Strongly disagree") to 5 ("Strongly agree").

\section{Method of Data Collection}

Self- administered questionnaire was floated to collect data from charge nurses. The 110 copies of questionnaire were circulated and given a free hand to complete it and return it.

\section{Method of Data Analysis}

Inferential statistics of Chi-square(x2) were used to analyze the association between the variable. Relibility assessed by the use of Cronbach's Alpha and its value of 0.70 was demonstrated that the questionnaire was reliable. Regression analyses was carried out to determine whether there was the linear trend between the variables. And senstivity analyses were used to examine the results. In the end, all the data were put into the software SPSS 21 version and the findings and results were drawn on the basis of statistical procedures.

\section{Time Framework}

This study was taken 3-4 months.

\section{Informed Consent}

Consent was taken from all the participant and free hand were given to the participants to take part in the study or refused to participate, participant were also be the right to mentioned name or not and confidentiality was considered. 


\section{Research Framework}

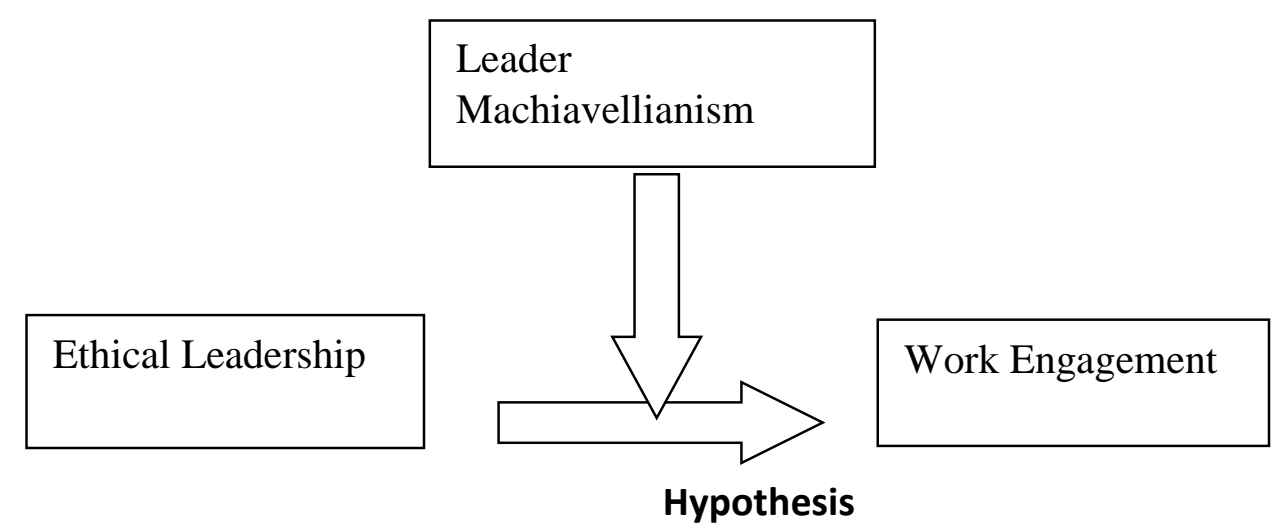

\section{Alternative Hypothesis}

- There is positive relationship between the ethical leadership and employee engagement.

- Machiavellianism does moderate the relationship of ethical leadership and employee engagement.

\section{Null Hypothesis}

- There is no positive relationship between the ethical leadership and employee engagement.

- Machiavellianism does not moderate the relationship of ethical leadership and employee engagement.

\section{Result}

Data was collected and analyzed by using the (SPSS. 21 Version) software. First analysis is demographic analysis in which 5 demographic questions include. Second analysis is correlational. Third regression analysis is used for the effect of ethical leadership on work engagement and to check the effect of moderation. Reliability and validity is also used.

\section{Demographic Analysis:}

Table no 1: Age

\begin{tabular}{|r|l|l|l|l|}
\hline & $\begin{array}{l}\text { Frequen } \\
\text { cy }\end{array}$ & Percent & Valid percent & $\begin{array}{l}\text { Cumulative } \\
\text { percent }\end{array}$ \\
\hline Valid 25-35 & 19 & 17.3 & 17.3 & 17.3 \\
$35-50$ & 79 & 71.8 & 71.8 & 89.1 \\
Total & 12 & 10.9 & 10.9 & 100.0 \\
& 110 & 100.0 & 100.0 & \\
\hline
\end{tabular}

Table no. 1 shows that the $17.3 \%$ respondent belong to $18-25$ yrs and $71.8 \%$ of $25-35 y$ rs and $10.9 \%$ of $35-50$ age group. 
INTERNATIONAL JOURNAL OF ACADEMIC RESEARCH IN BUSINESS AND SOCIAL SCIENCES Vol. 9, No. 3, March, 2019, E-ISSN: 222 2-6990 ¿ 2019 HRMARS

Table no 2: Gender

\begin{tabular}{|c|l|l|l|l|}
\hline & Frequency & Percent & Valid percent & $\begin{array}{l}\text { Cumulative } \\
\text { percent }\end{array}$ \\
\hline $\begin{array}{c}\text { Male } \\
\begin{array}{c}\text { Valid Female } \\
\text { Total }\end{array}\end{array}$ & 3 & 2.7 & 2.7 & 2.7 \\
& 110 & 97.3 & 97.3 & 100.0 \\
\hline
\end{tabular}

Table no. 2 and graph shows that $2.7 \%$ respondent are of male employee and $97.3 \%$ respondents are of female.

Table no 3: Marital status

\begin{tabular}{|c|l|l|l|l|}
\hline & Frequency & Percent & Valid percent & $\begin{array}{l}\text { Cumulative } \\
\text { percent }\end{array}$ \\
\hline $\begin{array}{c}\text { Married } \\
\text { Valid Single } \\
\text { Total }\end{array}$ & 46 & 41.8 & 41.8 & 41.8 \\
& 110 & 58.2 & 58.2 & 100.0 \\
\hline
\end{tabular}

Table no. 3 and graph shows that $46 \%$ of respondent are of married and $64 \%$ are of single.

Table no 4: Qualification

\begin{tabular}{|c|l|l|l|l|}
\hline & $\begin{array}{l}\text { Frequenc } \\
\mathrm{y}\end{array}$ & $\begin{array}{l}\text { Percen } \\
\mathrm{t}\end{array}$ & Valid percent & $\begin{array}{l}\text { Cumulative } \\
\text { percent }\end{array}$ \\
\hline Valid $\begin{array}{c}\text { Nursing } \\
\text { Diploma } \\
\text { BSN } \\
\text { Total }\end{array}$ & 99 & 90.0 & 90.0 & 90.0 \\
& 11 & 10.0 & 10.0 & 100.0 \\
\hline
\end{tabular}

Table no.4 shows that qualification of the respondent were recorded as $90 \%$ respondent are of general nursing diploma and $10 \%$ respondent are of BSN students. 


\section{Correlation Analysis}

Table no. 32

\begin{tabular}{|c|c|c|c|c|}
\hline & & EL & WE & $\mathrm{MC}$ \\
\hline \multirow{3}{*}{ EL } & Pearson & 1 & $.450 * *$ & $.388 * *$ \\
\hline & Correlation & & & \\
\hline & Sig.(2-tailed) & & .000 & .000 \\
\hline \multirow{5}{*}{ WE } & $\mathrm{N}$ & 110 & 110 & 110 \\
\hline & Pearson & $.450 * *$ & 1 & $.359 * *$ \\
\hline & Correlation & & & \\
\hline & Sig. (2-tailed) & .000 & & .000 \\
\hline & $\mathrm{N}$ & 110 & 110 & 110 \\
\hline \multirow{4}{*}{$\mathrm{MC}$} & Pearson & $.388 * *$ & $.359 * *$ & 1 \\
\hline & Correlation & & & \\
\hline & Sig. (2-tailed) & .000 & .000 & \\
\hline & $\mathrm{N}$ & 110 & 110 & 110 \\
\hline
\end{tabular}

Table no.32 Shows correlation among the variables. The result portrayed that ethical leadership was positively associated with work engagement $(.450 \mathrm{p}<.01)$ and also correlate with Machiavellianism but less than work engagement that is $(.388 p<.01)$. Similarly work engagement significantly correlated with Machiavellianism. Machiavellianism is significantly correlated with ethical leadership and work engagement. These results provided initial support to hypothesis formulated in the present study.

\section{Reliability and Validity Analysis}

\section{Reliability}

Reliability calculated through Cronbach's Alpha that illustrate reliability of each construct that how much it is reliable to use and duplicate it by changed scholars under condition to acquire the outcomes.

Independent Variable: Ethical leadership

Table no. 33

Reliability Statistics

\begin{tabular}{|r|c|}
\hline $\begin{array}{l}\text { Cronbach's } \\
\text { Alpha }\end{array}$ & N of items \\
\hline .849 & 11 \\
\hline
\end{tabular}


INTERNATIONAL JOURNAL OF ACADEMIC RESEARCH IN BUSINESS AND SOCIAL SCIENCES

Vol. 9, No. 3, March, 2019, E-ISSN: 222 2-6990 ¿ 2019 HRMARS

Dependent Variable: Work Engagement

Reliability Statistics

\begin{tabular}{|r|l|}
\hline $\begin{array}{l}\text { Cronbach's } \\
\text { Alpha }\end{array}$ & $\begin{array}{l}\text { N of } \\
\text { items }\end{array}$ \\
\hline .800 & \multicolumn{1}{|c|}{10} \\
\hline
\end{tabular}

Moderator Variable: Machiavellianism

Reliability Statistics

\begin{tabular}{|c|l|}
\hline $\begin{array}{l}\text { Cronbach's } \\
\text { Alpha }\end{array}$ & $\begin{array}{l}\text { N of } \\
\text { items }\end{array}$ \\
\hline .829 & \multicolumn{2}{|c|}{9} \\
\hline
\end{tabular}

Cronbach's Alpha value for ethical leadership is .849, Work engagement .800 and Machiavellianism is .829 . These values are greater than $0.70 \%$. Thus, result meet the standard requirement of reliability and this study variables are reliable.

\section{Validity}

Table no.34: KMO and Bartlett's Test

\begin{tabular}{|ll|l|}
\hline \multicolumn{2}{|l|}{ Kaiser- Meyer-Olkin Measure of Sampling } & .655 \\
Adequacy. & \multicolumn{1}{|c|}{ Approx. Chi- Square } & 47.222 \\
$\begin{array}{l}\text { Bartlett's Test } \\
\text { Sphericity }\end{array}$ & Df & 3 \\
& Sig. & .000 \\
\hline
\end{tabular}

Instrument consisting of independent variable, dependent variable and moderator variable. Table no.34 shows that KMO value is above .50 and Bartlett's test significant value is $(p<0.05)$. So, that total standards were satisfied, and instrument of this study are valid.

\section{Regression Analysis:}

It is statistical test use to check the effect of one variable to another variable.

Table no.35: Model Summary

\begin{tabular}{|l|l|l|l|l|}
\hline $\begin{array}{l}\text { Mode } \\
1\end{array}$ & $\mathrm{R}$ & R Square & Adjusted R Square & $\begin{array}{l}\text { Std. Error of } \\
\text { the Estimate }\end{array}$ \\
\hline 1 & $.450 \mathrm{a}$ & .202 & .195 & .42518 \\
\hline
\end{tabular}

Table no.35 shows that total variation of $20.2 \%$ in work engagement is explained by ethical leadership. 
Table no.36 ANOVA

\begin{tabular}{|ll|l|l|l|l|l|}
\hline \multicolumn{2}{|l|}{ Model } & $\begin{array}{l}\text { Sum of } \\
\text { Squares }\end{array}$ & Df & $\begin{array}{l}\text { Mean } \\
\text { Square }\end{array}$ & F & Sig. \\
\hline \multirow{2}{*}{1} & Regression & 4.947 & 1 & 4.947 & 27.366 & $.000^{\mathrm{b}}$ \\
& Residual & 19.524 & 108 & .181 & & \\
& Total & 24.472 & 109 & & & \\
\hline
\end{tabular}

a. Dependent Variable: WE

b. Predictors: (Constant), EL

Table no.36 shows the interaction of ANOVA and result revealed that ANOVA is significant and $p<$ 0.05 , So research model is fit.

Table no.37: Coefficients

\begin{tabular}{|c|c|c|c|c|c|}
\hline \multirow[t]{2}{*}{ Model } & \multicolumn{2}{|c|}{$\begin{array}{l}\text { Unstandardized } \\
\text { coefficient }\end{array}$} & \multirow{2}{*}{$\begin{array}{l}\text { Standardized } \\
\text { coefficient } \\
\text { Beta }\end{array}$} & \multirow[t]{2}{*}{$\mathrm{T}$} & \multirow[t]{2}{*}{ Sig. } \\
\hline & B & Std. Error & & & \\
\hline $\begin{array}{l}\text { (Constant } \\
\text { ) }\end{array}$ & 2.226 & .302 & & 7.366 & .000 \\
\hline EL & .423 & .081 & .450 & 5.231 & .000 \\
\hline
\end{tabular}

a. Dependent Variable: WE

Table no. 37 shows that the impact of ethical leadership have significant positive $(p<0.05, t=5.231)$ relationship with work engagement. It also shows increase of one unit in the EL cause the change of beta value of 0.423 in the work engagement.

\section{Moderating effect of Machiavellianism:}

Model $=1$

$Y=W E$

$X=E L$

$M=M C$

Sample size

110

Table no. 37

Model Summary

$\begin{array}{cccccccc}R & \text { R-sq } & \text { MSE } & F & \text { df1 } & \text { df2 } & p & \\ .5081 & .2582 & .1713 & 12.2958 & 3.0000 & 106.0000 & .0000 \\ \text { Model } & & & & & & \end{array}$


INTERNATIONAL JOURNAL OF ACADEMIC RESEARCH IN BUSINESS AND SOCIAL SCIENCES

Vol. 9, No. 3, March, 2019, E-ISSN: 222 2-6990 @ 2019 HRMARS

$\begin{array}{lccccccc} & \text { coeff } & \text { se } & \mathrm{t} & \mathrm{p} & \mathrm{LLCl} & \mathrm{ULCl} & \\ \text { Constant } & -.2782 & 1.4935 & -.1863 & .8526 & -3.2393 & 2.6828 \\ \text { MC } & .8749 & .4690 & 1.8653 & .0649 & -.0550 & 1.8048 \\ \text { EL } & .9262 & .3974 & 2.3309 & .0217 & .1384 & 1.7140 \\ \text { int_1 } & -.1835 & .1222 & -1.5012 & .1363 & -.4259 & .0588\end{array}$

Table no.37 shows that the total variation of 25.82 percent in work engagement is explained by ethical leadership that is the direct relationship of EL and WE which is significant because $p$ value is less than 0.05 and Machiavellianism as a moderation in interaction term is insignificant because $p$ value is .1363 which is greater than 0.05 . So, the model is insignificant.

\section{Result and Discussion}

The demographic analysis of the Nurses data mostly the participant's nurses were females range of nurse age was between 25 to 35 years. Age of the nurses were 18-25 years of staff nurses which were $19(17.3 \%)$ and the 25 - 35years $79(71.8 \%), 35-50$ years of age were $12(10.9 \%)$. Nurses $46(41.8 \%)$ participating in this study were married, and the other respondents 64(58.2\%) were unmarried. The demographic analysis of the patients' data most of the participants were Female 107(97.3\%) and male participants were 3(2.7\%). Most of the respondents were general nursing diploma $99(90 \%)$ and some other respondents are of BSN 11 (10.0\%).

The purpose of this study is to examine the association between ethical leadership and its result have on work engagement employee and to check the part of leader Machiavellianism. This study indicate that Machiavellian leaders capable to start same encouragement in their employees as in authentic leader where as Deluga (2001) revealed that followers often seen Machiavellian leaders as charismatic. This study found that Machiavellian leaders show ethical leaders reactions to their supporters and benefit from the motivational leadership (Den Hartog \& Belschak 2012). Regression analysis was carry out to observe the association between ethical leadership and work engagement. The consequences of linear regression reveal beta value .450 ( $p=.000)$ show the significant constructive association of ethical leadership and work engagement. Correlation analysis Shows correlation among the variables. The result reveal that ethical leadership was positively correlated with work engagement $(.450 \mathrm{p}<.01$. Similarly work engagement significantly correlated with Machiavellianism. Machiavellianism as a moderator is insignificantly correlated with ethical leadership and work engagement.

Research suggest that employees, engagement with their work is an essential predictor of task pride and intentions to remain within the organization. Developing situation that work engagement is an crucial mandate of nurse management and a key element of any recruitment and retention (Laschinger and Finegan 2005). People who wrote about the work engagement process believes that representatives and followers gives higher output or show more interest when they see that their pioneers are more cooperative gives more dedication to work (Harter, Schmidt et al. 2002). Research finding recommend that subordinate differentiate between authentic and inauthentic expression of ethical leadership as in the association between ethical leadership and work engagement. When leaders are high Machiavellian productivity of work decreased as compared to those when leader shows less Machiavellianism expression 


\section{Conclusions}

The aim of this study is to examine the association between ethical leadership and its result have on work engagement employee and to assess the part of leader Machiavellianism. The result portrayed that ethical leadership was positively correlated with work engagement and also correlate with Machiavellianism but less than work engagement. Machiavellianism is insignificantly correlated with ethical leadership and work engagement.

Ethical and applicable reasons, immoral behavior and relationship conflict is decreased if institution is interested. Leaders should set the ethical climate and are encouraging ethical behavior and reducing interpersonal tension from their subordinates. This study indicates that work engagement increases if leader are moral individuals and influence behavior by using reward and punishment systems.

\section{Limitation and Future Research}

The main limitation of this study was a shortage of time. The study was also restricted to one hospital. The relationship among ethical leadership and work engagement turns into bad as soon as fans start to intestinally comprehend that Machiavellian leader artificially their principled ethics. The study also measured the variables at specific fact in time, however certain methods may only explain over time. The study findings should be understood with this in attention, and future investigational and longitudinal research is necessary in the part to talk this limitation. Each variable might possibly cause the other.

\section{References}

Brown, M. E. and L. K. Treviño. (2006). "Ethical leadership: A review and future directions." The leadership quarterly 17(6): 595-616.

development and testing." Organizational behavior and human decision processes 97(2): 117-134. Demirtas, O. (2015). "Ethical leadership influence at organizations: Evidence from the field." Journal of Business ethics 126(2): 273-284.

Hartog, D. N. and F. D. Belschak (2012). "Work engagement and Machiavellianism in the ethical leadership process." Journal of Business ethics 107(1): 35-47.

Hassan, A. and Ahmed, F. (2011). "Authentic leadership, trust and work engagement." International journal of human and social sciences 6(3): 164-170.

Hunter, S. T. (2012). "(Un) ethical leadership and identity: what did we learn and where do we go from here?" Journal of Business ethics 107(1): 79-87.

Laschinger, H. K. S. and J. Finegan. (2005). "Empowering nurses for work engagement and health in hospital settings." Journal of nursing administration 35(10): 439-449

Schaufeli, W. B., et al. (2006). "The measurement of work engagement with a short questionnaire: A cross-national study." Educational and psychological measurement 66(4): 701-716.

Walumbwa, F. O. and J. Schaubroeck. (2009). "Leader personality traits and employee voice behavior: mediating roles of ethical leadership and work group psychological safety." Journal of Applied Psychology 94(5): 1275. 